\title{
TOTAL PHENOLIC AND FLAVONOID CONTENT, ANTIOXIDANT ACTIVITY OF FICARIA VERNA
}

\author{
Viktoriia Karpiuk \\ Postgraduate Student at the Department of Technology of Biologically Active Substances, \\ Pharmacy and Biotechnology, Lviv Polytechnic National University, Ukraine \\ e-mail: viktoriia.r.liakh@1pnu.ua, orcid.org/0000-0002-7996-5352,
}

\section{Roksolana Konechna}

Ph.D., Associate Professor, Lviv Polytechnic National University, Ukraine e-mail: roksolana.t.konechna@1pnu.ua, orcid.org/0000-0001-6420-9063

\section{Summary}

The objective of the present study was to determine the total content of phenolics and flavonoids in ethanol extracts of a plant from the family of Ranunculaceae - Ficaria verna. Harvesting of medicinal plant was carried out in ecologically clean regions of west Ukraine in spring 2020. The extracts were obtained by maceration of grass, leaves, and flowers to compare the content of active substances in different types of raw materials.

The total phenolic content was estimated spectrophotometrically using Folin Ciocalteu method. The total flavonoid content was measured by aluminium chloride colorimetric assay. The maximum content of phenolic and flavonoids compounds was observed in the grass Ficaria verna. The antioxidant effects of the extracts were investigated. The Ficaria verna can be regarded as a promising natural plant source of antioxidant effects with a high potential for phytopreparations.

Keywords: Ranunculaceae, extracts, bioactive compounds, biological activity.

DOI: https://doi.org/10.23856/4630

\section{Introduction}

Despite significant advances in the modeling and creation of synthetic drugs, the popularity of herbal therapy is increasing and its competence is expanding. Today, the world pharmaceutical industry is making extensive use of herbal raw materials, which are the basis for the creation of medicines. Medicinal plants contain evolutionarily formed complexes of native substances engaged in complex interactions.

A large number of drugs that are manufactured worldwide have natural ingredients of plant origin. Natural drugs are known to have a milder effect than synthetic agents. Undesirable side effects of drugs, including those of synthetic origin, are observed in $10-40 \%$ of patients and are one of the obstacles in the development of new drugs. The percentage of side effects significantly increases during self-medication. Thus in more than $60 \%$ of cases of self-medication, there was observed irrational and unjustified use of drugs. So it is promising to expand the range of herbal medical products with new effective plant-based preparations, in particular those based on the herbs widely used in ethnomedicine.

Therefore, the search for new species of plants that could be a source of biologically active compounds, such as flavonoids, coumarins, hydroxycoric acids, alkaloids, saponins, amino acids, and so on. One of the most relevant and promising representatives of the Ukrainian 
flora to be used in modern medicine and pharmacy is a plant from the family of Ranunculaceae-Ficaria verna. This plant is typical for the ethnopharmacology of East Slavic peoples. It has been used to treat bronchitis, tracheitis, hemorrhoids, skin rashes, acne, diathesis, gingivitis, polyarthritis, stomatitis, and wounds.(Liakh and Konechna, 2021)

The complex of bioactive compounds of plant Ficaria verna has diuretic, expectorant, anti-inflammatory and blood purifying properties.

The Ficaria verna growth range extends from Europe and North Africa to West Asia. Plant populations were found in Belarus, Croatia, Germany, Lithuania, Spain, Algeria, Libya, Tunisia, Israel, Turkey, and Georgia. It was introduced into North America. (Karpiuk, et al., 2020)

In Ukraine, it is widespread throughout the territory. it occurs in wet forests, mostly deciduous, often along watercourses, in thickets of shrubs. Ficaria verna contains biologically active substances in both primary and secondary synthesis. It consists of saponins, $\gamma$-lactones: protoanemonin, anemonin, ascorbic acid (190 mg \%), carotene (5,2 mg \%). Starch (13.5\%), sugars $(10 \%)$ have been found in underground organs. It also contains triterpenoid saponins. (Hrodzins'kyy, 1992)

Ficaria verna flowers contain flavonoid compounds (kaempferol 3-O- $\beta$-d- $(6 "-\alpha-1-$ rhamnopyranosyl)-glucopyranoside (nicotiflorin), apigenin 8-C- $\beta$-d-glucopyranoside (vitexin), luteolin 8- C- $\beta$-d-glucopyranoside (orientin) and apigenin $8-C-\beta-d-(2$ "-O- $\beta$-d-gluco-pyranosyl)-glucopyranoside (flavosativazide)), flavonol triglycosides (3-O-[alpha-L-rhamnopyranosyl-(1-6)-beta-D-glucopyranosyl]-7-O-(beta-D-glucopyranosyl)-quercetin (1) and 3-O-[alpha-L-rhamnopyranosyl-(1-6))-beta-D-glucopyranosyl]-7-O-(beta-D-glucopyranosyl (kaempferol)), triterpenes and stearins. (Gudej and Tomczyk,1999)

Lactone protoanemonin, the main component of the plant, is toxic, but after drying the toxic properties are lost because protoanemonin is converted into anemonin. All parts of the plant contain protoanemonin, but the highest content is found in stems and flowers. Ficaria verna leaves contain fewer flavonoids than flowers. The main components in the leaves are derivatives of the $\mathrm{C}$-glycoside apigenin and luteolin. Ranulinculin and its breakdown products are observed in a raw. (Tomczyk and Gudej,2003; Tomczyk and Gudej,2002)

The purpose of our study is to investigate the chemical composition of the ethanol extracts of Ficaria verna., in particular, phenolic compounds and flavonoids, and to study their and antioxidant effects.

\section{Material and method}

\subsection{Plant material}

Harvesting of medicinal plant material (Ficaria verna. herb, leaves, and flowers) was carried out in ecologically clean regions of west Ukraine in spring 2020. Drying and standardization were carried out according to the requirements of the State Pharmacopoeia of Ukraine. (Derzhavna Farmakopeya Ukrayiny. Dopovnennya 2).

\subsection{Preparation of extracts}

The extracts were obtained by maceration from each type of raw material separately. To compare the content of active substances prepared extracts of grass (FH), leaves(FL), and flowers (FF). Aqueous ethanol solutions in concentrations of 20\% (FH1, FV1, FF1 extracts), 40\% (FH2, FL2, FF2 extracts), 70\% (FH3, FL3, FF3 extracts) and 90\% (FH4, FL4, FF4 extracts) were used as extractants. The ratio of raw material and extractant was 1:10. 


\subsection{Determination of total phenolic content}

The determination was performed using a spectrophotometric analysis using a modified Folin-Ciocalteu method. $0,1 \mathrm{ml}$ of Folin reagent, $1,5 \mathrm{ml}$ of distilled water, and $0,3 \mathrm{ml}$ of $20 \%$ $\mathrm{Na}_{2} \mathrm{CO}_{3}$ solution were added to $0,1 \mathrm{ml}$ of the analyzed solution, diluted in a ratio of 1:10. Kept for $150 \mathrm{~min}$ in the dark place

The optical density of the resulting solution was measured at $760 \mathrm{~nm}$. The conversion was performed per gallic acid according to a calibration curve that was constructed under similar conditions, replacing the analyte with the gallic acid solution used as standard. A 3-fold measurement was performed for data validity (Skotti et al., 2014; Krvavich et al., 2019).

\subsection{Determination of total flavonoid}

The number of flavonoids was determined by a modified spectrophotometric method by the complexation reaction of flavonoids with $\mathrm{AlCl}_{3}$. For this purpose, a 5\% solution of $\mathrm{NaNO}_{2}$, a $0.1 \mathrm{M}$ solution of sodium hydroxide $\mathrm{NaOH}$, and a $10 \%$ solution of $\mathrm{AlCl} 3$ were prepared. $0.2 \mathrm{ml}$ of the obtained Ficaria verna. herb extract was taken into a test tube and dissolved in $0.8 \mathrm{ml}$ of ethyl alcohol. $0.06 \mathrm{ml}$ of $5 \%$ sodium nitrite solution was added and mixed. After that, the tube was kept for $5 \mathrm{~min} .0 .06 \mathrm{ml}$ of a $10 \%$ solution of aluminum chloride was added and kept for 5 min until the reaction was complete. Then $0.4 \mathrm{ml}$ of $0.1 \mathrm{M}$ sodium hydroxide solution and $0.480 \mathrm{ml}$ of ethyl alcohol were added. After that, the tube was kept for 5 min in a dark place.

The measurements were performed at a wavelength of $510 \mathrm{~nm}$. For calibration, a standard curve was constructed using the solution of quercetin as standard, and the content of flavonoids was determined in terms of quercetin. A 3-fold measurement was performed for the accuracy of the data ( Do et al., 2014).

\subsection{Determination of the antioxidant effect}

\subsubsection{DPPH radical scavenging effect}

The DPPH method of measuring the antioxidant effect of the extract was used with some modifications. Freshly prepared solution of DPPH was about $0.1 \mathrm{mM}(0.2 \mathrm{~g}$ DPPH in $500 \mathrm{~mL}$ of ethanol). $4.5 \mathrm{~mL}$ of solution of DPPH and $500 \mu \mathrm{L}$ of the extract were mixed in a test tube, which was incubated for 30 minutes in the dark at room temperature. A UV-VIS spectrophotometer was used for measuring the decrease in absorbance (at $517 \mathrm{~nm}$ ). (Konechna, R.et al.,2017)

The following formula was used for calculating percentage of inhibition of the radicals:

$\%$ inhibition $=($ Acontrol - Asample $) /$ Acontrol $\times 100 \%$

where Acontrol is the absorbance of DPPHsolution without extract and Asample is the absorbance of the sample with the added DPPH solution. A 3-fold measurement was performed for the accuracy of the data (Do et al., 2014).

\section{Results}

\subsection{Total phenolic and flavonoid contents}

The total content of phenolic compounds in the investigated extracts was determined, the result is expressed in $\mathrm{mg}$ of gallic acid per $\mathrm{g}$ of plant material. The total content of flavonoids was determined, the result is expressed in $\mathrm{mg}$ of quercetin per $\mathrm{g}$ of plant material. The results are presented in Table 1, Table 2, Table 3. 
Table 1

Total phenolic and flavonoid content of Ficaria verna herb extracts

\begin{tabular}{|c|c|c|}
\hline Sample & $\begin{array}{c}\text { Total phenolic content } \\
\text { (mg gallic acid/g), } \mathbf{n}=\mathbf{3}\end{array}$ & $\begin{array}{c}\text { Total flavonoid content } \\
\text { (mg quercetin/g) } \mathbf{n}=\mathbf{3}\end{array}$ \\
\hline FH1 & $15,8 \pm 0,01$ & $7,41 \pm 0,01$ \\
\hline FH2 & $16.75 \pm 0,01$ & $9,16 \pm 0,01$ \\
\hline FH3 & $20,35 \pm 0,01$ & $18,37 \pm 0,01$ \\
\hline FH4 & $18,65 \pm 0,01$ & $12,975 \pm 0,01$ \\
\hline
\end{tabular}

It was found that among the extracts from the herb Ficaria verna the maximum content of both phenolic compounds and flavonoids was observed in $70 \%$ of water-ethanol extracts.

The content of flavonoids in the tested extracts ranged from 7,41 to $18,37 \mathrm{mg}$ quercet$\mathrm{in} / \mathrm{g}$. The highest value was observed for the FH3 extract, the extractant being $70 \%$ aqueous-ethanol solution.

Table 2

Total phenolic and flavonoid content of Ficaria verna leaves extracts

\begin{tabular}{|c|c|c|}
\hline Sample & $\begin{array}{c}\text { Total phenolic content } \\
\text { (mg gallic acid/g) } \mathbf{n}=\mathbf{3}\end{array}$ & $\begin{array}{c}\text { Total flavonoid content } \\
\text { (mg quercetin/g) } \mathbf{n}=\mathbf{3}\end{array}$ \\
\hline FL1 & $8.3 \pm 0,01$ & $3.38 \pm 0,01$ \\
\hline FL2 & $8.97 \pm 0,01$ & $4.15 \pm 0,01$ \\
\hline FL3 & $11.58 \pm 0,01$ & $10.37 \pm 0,01$ \\
\hline FL4 & $8.97 \pm 0,01$ & $0.675 \pm 0,01$ \\
\hline
\end{tabular}

It was found that among the extracts from leaves of Ficaria verna the maximum content of both phenolic compounds and flavonoids was observed in $70 \%$ of water-ethanol extracts.

The content of flavonoids in the tested extracts ranged from 0.675 to $10,37 \mathrm{mg}$ quercet$\mathrm{in} / \mathrm{g}$. The highest value was observed for the FL3 extract, the extractant being $70 \%$ aqueous-ethanol solution.

Table 3

Total phenolic and flavonoid content of Ficaria verna flowers extracts

\begin{tabular}{|c|c|c|}
\hline Sample & $\begin{array}{c}\text { Total phenolic content } \\
\text { (mg gallic acid/g) } \mathbf{n}=\mathbf{3}\end{array}$ & $\begin{array}{c}\text { Total flavonoid content } \\
\text { (mg quercetin/g) } \mathbf{n}=\mathbf{3}\end{array}$ \\
\hline FF1 & $5.87 \pm 0,01$ & $2.15 \pm 0,01$ \\
\hline FF2 & $6.23 \pm 0,01$ & $2.89 \pm 0,01$ \\
\hline FF3 & $8.51 \pm 0,01$ & $6.32 \pm 0,01$ \\
\hline FF4 & $7.35 \pm 0,01$ & $0.386 \pm 0,01$ \\
\hline
\end{tabular}

It was found that among the extracts from flowers of Ficaria verna the maximum content of both phenolic compounds and flavonoids was observed in $70 \%$ of water-ethanol extracts.

The content of flavonoids in the tested extracts ranged from 0.386 to $6.32 \mathrm{mg} / \mathrm{g}$. The highest value was observed for the FF3 extract, the extractant being 70\% aqueous-ethanol solution.

The maximum content of phenolic compounds and flavonoids was observed in extracts with the herb Ficaria verna, the lowest content in extracts from the flowers of Ficaria verna. 


\subsection{Antioxidant activity}

For the evaluation of the antioxidant activity of single compounds has been widely used relatively stable organic radical DPPH as well as the different plant extracts.

A rapid decrease in the optical density at $517 \mathrm{~nm}$ was induced by the addition of extracts to the DPPH solution.

The effect of Ficaria verna extracts of different concentrations in comparison with quercetin and vitamin $\mathrm{C}$ on the inhibition of DPPH radical is shown in Table 4, Table 5, and Table 6.

DPPH radical scavenging activity of Ficaria verna herb extracts

\begin{tabular}{|c|c|}
\hline Sample & \% inhibition of DPPH* \\
\hline FH1 & $80,71 \pm 0,01$ \\
\hline FH2 & $78,94 \pm 0,01$ \\
\hline FH3 & $77,19 \pm 0,01$ \\
\hline FH4 & $75,43 \pm 0,01$ \\
\hline Vitamin C & $76,23 \pm 0,01$ \\
\hline Quercetin & $78,54 \pm 0,01$ \\
\hline
\end{tabular}

Table 5

DPPH radical scavenging activity of Ficaria verna leaves extracts

\begin{tabular}{|c|c|}
\hline Sample & \% inhibition of DPPH* \\
\hline FL1 & $67,33 \pm 0,01$ \\
\hline FL2 & $63,02 \pm 0,01$ \\
\hline FL3 & $62,33 \pm 0,01$ \\
\hline FL4 & $61,86 \pm 0,01$ \\
\hline Vitamin C & $76,23 \pm 0,01$ \\
\hline Quercetin & $78,54 \pm 0,01$ \\
\hline
\end{tabular}

Table 6

DPPH radical scavenging activity of Ficaria verna flowers extracts

\begin{tabular}{|c|c|}
\hline Sample & \% inhibition of DPPH* \\
\hline FF1 & $8,71 \pm 0,01$ \\
\hline FF2 & $7,94 \pm 0,01$ \\
\hline FF3 & $77,19 \pm 0,01$ \\
\hline FF4 & $75,43 \pm 0,01$ \\
\hline Vitamin C & $76,23 \pm 0,01$ \\
\hline Quercetin & $78,54 \pm 0,01$ \\
\hline
\end{tabular}

Our investigation shows that the free radical scavenging ability of FH1, FH2 -extracts was better than quercetin. The free radical scavenging ability of FH1, FH2, and FH3 extracts were better than Vitamin $\mathrm{C}$.

The results prove that $\mathrm{FH} 1, \mathrm{FH} 2$ extracts improve the scavengers of radical DPPH cations more than vitamin $\mathrm{C}$ or quercetin. 


\section{Conclusions}

The research done into the chemical composition of Ficaria verna ethanol extracts discovered the quantitative content (strength) of phenol compounds and flavonoids as well as examined their antioxidant effects

Sufficient content phenolic compounds and flavonoids as well as the detected antioxidant effects allow us to consider Ficaria verna a promising medicinal plant for the development of herbal preparations and further research of the plant.

\section{References}

Derzhavna Farmakopeya Ukrayiny. Dopovnennya 2. [State Pharmacopoeia of Ukraine. Appendix 2.] (2008). Kharkiv : Derzhavne pidpryyemstvo „Naukovo-ekspertnyy farmakopeynyy tsentr". [in Ukrainian]

Do, Q. D. (2014). Effect of extraction solvent on total phenol content, total flavonoid content, and antioxidant activity of Limnophila aromatica. Journal of Food and Drug Analysis, 22, 296-302. DOI:10.1016/j.jfda.2013.11.001. [in English].

Gudej J., \& Tomczyk M. (1999). Polyphenolic compounds from flowers of Ficaria verna Huds. Acta Pol.Pharm. - Drug Res. 56, 475-476 [in English].

Hrodzins'kyy A.M. (1992). Likars'ki roslyny: Entsyklopedychnyy dovidnyk. [Medicinal plants: Encyclopedic reference book]. (pp. 368-369). Kyiv: "Ukrayins'ka Entsyklopediya» im. M. P. Bazhana, Ukrayins'kyy vyrobnycho-komertsiynyy tsentr «Olimp». [in Ukrainian]

Karpiuk V., Yuzkiv S., Konechnyi Yu., Zhurakhivska L., Konechna R. (2020) FICARIA VERNA. Analitychnyy ohlyad. [FICARIA VERNA. Analytical review.]. Fitoterapiya.Chasopys - Phytotherapy. Magazine, 4, 40. [in Ukrainian]

Konechna, R., Khropot, O., Petrina, R., ...Gubriy, Z., Novikov, V. (2017).Research of antioxidant properties of extracts of the plants and the callus biomass. Asian Journal of Pharmaceutical and Clinical Research, 7, 182-185 [in English].

Krvavych, A.S., Hamada, V.R., Konechna, R.T., ...Buchkevych, I.R., Novikov, V.P. (2019) Extraction of phenolic compounds from the plant Adonis vernalis. Voprosy khimii $i$ khsmscheskoi tekhnolohii, 5, 54-57. [in Ukrainian]

Liakh, V. R., \& Konechna, R. T. (2021). Prycladni aspekty zastosuvannia likars'kykh roslyn rodyny Ranunculaceae $v$ etnomedytsyni ta farmatsiyi. [Applied aspects of the use of medicinal plants of the family Ranunculaceae in ethnomedicine and pharmacy]. Publishing House “Baltija Publishing”. DOI: 10.30525/978-9934-26-024-7-10 [in Ukrainian]

Tomczyk, M., \& Gudej, J. (2003). Quantitative Analysis of Flavonoids in the Flowers and Leaves of Ficaria verna Huds. Zeitschrift Für Naturforschung C, 58(9-10), 763-765. [in English].

Tomczyk M., \& Gudej J. (2002). Quercetin and kaempferol glycosides from Ficaria verna flowers and their structure studied by 2D NMR spectroscopy. Polish Journal of Chemistry. [in English].

Skotti, E. (2014). Total phenolic content, antioxidant activity and toxicity of aqueous extracts from selected Greek medicinal and aromatic plants. Industrial Crops and Products, 53, 46- 54. DOI:10.1016/j.indcrop.2013.12.013. [in English]. 